\title{
Teaching Music from the Perspective of First, Second and Third Grade Students of Primary School
}

\author{
Vesna Svalina ${ }^{1}$, Jelena Zelić \\ 1 Josip Juraj Strossmayer University of Osijek, Faculty of Education, 10 Cara Hadrijana St., HR-31000 Osijek, \\ Croatia, vesna.svalina@gmail.com \\ 2 Josip Juraj Strossmayer University of Osijek, Faculty of Education, 10 Cara Hadrijan, St., HR-31000 Osijek, \\ Croatia, jelena.zelic19@gmail.com
}

\begin{abstract}
This article examines the preferences of first, second, and third grade primary school students towards activities carried out in music teaching. The results of the research showed that in music teaching, singing activities are most commonly performed, and students prefer to participate in musical games. The results also showed that there were significant differences in students' responses to their satisfaction with playing Orff instruments and musical creativity activities according to their age.
\end{abstract}

Keywords: lower grades of primary school, music activities, music teaching, students, student preferences.

\section{Introduction}

According to the Croatian National Curriculum Framework (2011) and the existing Primary School Curriculum (2006), music in Croatian primary schools is taught in all eight grades within a course called Music Culture. The annual fund for regular music teaching is 35 hours, that is, one lesson per week. In the first three grades of primary school music classes are taught by class teachers, while from the fourth-grade music lessons can be conducted by the class teacher or specialized music teacher. From fifth to eighth grade music classes are regularly taught by a specialized music teacher. 
There are two basic principles underlying the teaching of music in Croatian schools. These are the psychological principle and the cultural-aesthetic principle. "The psychological principle considers the fact that, as a rule, students love music and that they want to actively engage in music (singing, playing an instrument). To the most extent, these wishes of students should be respected, because of their age, and then the school, are not only the time and place of preparation for life, but they are life itself" (Primary School Curriculum, 2006, 66). The second is the cultural-aesthetic principle, which is based on the idea that teaching music to students must prepare them for life and enable them to be a competent user of music culture from a school age, which is extremely important in today's world where students are exposed to all kinds of music.

According to the Primary School Curriculum (2006), the goal of music teaching is to introduce students to music culture, to learn the basic elements of musical language, to develop musical creativity, or to establish and adopt value standards for (critical and aesthetic) assessment of music.

In the first three grades of music teaching, the student's music activity is the focus, not the teaching content. "In the act of singing (any good and appropriate song) and listening (any good and appropriate composition), music is experienced and learned on the spot, enriches the student's emotional world, and sharpens his artistic sensibility" (Rojko, 2012, 133). In music teaching, students should sing, listen to music, move to music, dance and play. Music should serve to promote positive emotions, stimulate positive emotions, feelings of belonging, and a sense of community (Primary School Curriculum, 2006).

\section{Music Activities in Music Teaching}

Since 2006, an open model of music teaching has been applied in Croatian schools. This is a model "in which the compulsory part is to listen to music and become familiar with it, while the elective part is selected by the teacher in accordance with students' affinities" (Vidulin et al., 2015, 68). In addition, the teacher is also free to choose songs to sing or play, as well as compositions to listen to. Within the compulsory part of the curriculum (listening to music), students learn about artistic, folk, popular, and jazz music (Rojko, 2012; Svalina, 2015).

\section{Singing}

Singing is an activity that has always been present in music teaching because singing is the most elemental, spontaneous, and natural way of expressing a person in music. As such, singing has given an important mark in the history of music teaching, and good experiences through singing in school are essential for a lifelong interest in music (Lamont et al., 2012; Pitts, 2009; Radočaj-Jerković, 2017; Spruce, 2002; Vidulin, \& Terzić, 2011). 
The Croatian Primary School Curriculum $(2006,68)$ states that singing involves the continuous performance of songs without obligatory memorization of the text. Singing "develops a sense of accurate intonation and rhythm, musical memory and confidence." In music teaching, teachers should strive for good singing, which means that "good, expressive singing, clear articulation, comprehension of the text, and adequate musical interpretation should be achieved" (Vidulin-Orbanić, \& Terzić, 2011, 144). However, there are also some difficulties in the classroom when performing this activity, such as students' different vocal abilities, voice maturity, voice colour, and voice range.

In Croatian primary schools, singing is usually functional, which means that the emphasis is on relaxation, joy, optimism, and other extrinsic elements when conducting this activity. Most often children's and folk songs are sung whose quality varies from very valuable to those of no great value. Radočaj-Jerković (2017) believes that it is not necessary to avoid functional singing in music teaching. It is necessary for the development and improvement of vocal technique, i.e. as technical exercises that serve to acquire the skill of singing and as motivation for further work.

The results of a survey conducted in primary schools in Osijek-Baranja County (Svalina, 2015) showed that singing is the most important activity for teachers. Teachers most often perform singing activities in music teaching and find that they are the most competent to perform that music activity.

\section{Listening to Music}

Listening to music is one of the youngest areas in music teaching. It first appeared in the curriculum in Croatia in 1950, mentioning radios and gramophone. Listening to music is then cited as a recommendation and depends on the school's equipment. The 1972 curriculum also provides an extensive list of works for listening and for illustrating musical phenomena (instruments, musical forms, expressive elements, etc.), and listening appears under the title Knowledge of Music Literature. The next 1984 program featured an even greater number of works to listen to, and instead of the illustration function of music, music was given the function of learning about music and developing musical taste. With the 2006 curriculum, listening is emerging as the only compulsory area, whereby listening experiences full acceptance and affirmation (Rojko, 2012; Svalina, 2015). Within this teaching area, "the ability of auditory concentration, hearing specifications (the ability to recognize sounds and colours of different voices and instruments), the analysis of the work performed and the basic aesthetic criteria for evaluating music are developed" (Primary School Curriculum, 2006, 68).

At the primary level of education, it is also envisaged to carry out music listening activities in music teaching, without limitation to compositions determined by the program or intended exclusively for children. Other works can be listened to, with the focus on the duration of the compositions being selected due to limited children's attention (Rojko, 2012; Svalina, 2015). The results of previous studies show that younger students are more 
accepting of different and unknown musical styles and that they have greater preferences of all styles compared to older students (Dobrota, \& Reić Ercegovac, 2016; Fung, Lee, \& Chung, 1999/2000; Wiggins, 2001). Therefore, children should be introduced to music of different styles from young school age and listening to music should be a prominent teaching area and equally represented in all grades at the primary level of education.

When listening to music, emphasis should be placed on musical and expressive components (artist, tempo, dynamics, form, and atmosphere). Listening to music should be performed in such a way that the listening is repeated several times, and each time a new task is set to refer to the stated musical expressive components. Students need to come up with their own solutions to the problem solely by hearing. Dobrota and Curković (2006) state that listening tasks emphasize the importance of developing musical memory by listening and adopting classical and traditional music through different works. For the listening tasks to be accomplished, it is necessary to carry out active listening, in which the tasks must be purely musical in nature, and the students come to the solutions without theorizing and definitions, therefore, exclusively by their hearing.

According to the results of a study conducted in schools in Osijek-Baranja County (Svalina, 2015), listening to music is the second most important activity and the second most frequently used in music teaching. According to the teachers, their competencies for conducting music listening activities are very good, but not as good as competencies for conducting singing activities.

\section{Playing an Instrument}

Based on Orff's conception, playing an instrument was introduced in 1958 in Croatian general education schools. Playing an instrument in the lower grades of primary school is realized on the Orff Instrumentation. Various percussion instruments should be used in the course, and the Croatian methodical manuals also discuss their characteristics in detail. The introduction of playing an instrument in music teaching at the primary level of education is justified by both psychological and musical reasons. Namely, it is an activity "that students love and that makes teaching diverse, and which also develops their rhythmic abilities" (Dobrota, 2012, 28). This activity develops in the students a sense of rhythm, meter, precise coordination and collaboration. It contributes to a faster and more complete understanding of music, enhances students' creative activity and brings a lot of joy to the life of the class (Svalina, 2015).

According to Vidulin (2018), playing an instrument should focus on playing, recognizing, analyzing and demonstrating "various types of melody movements (ascending, descending, leaping, gradually, within tonality, outside of tonality, in different ranges) and rhythms (simple and complex rhythms, punctured rhythms)" (Vidulin, 2018, 140). Furthermore, students need to play in different measures, tempo and agogics. The phrasing and aesthetics of the composition are also important when playing, should be achieved to the fullest extent possible, and its achievement depends on the skills and knowledge 
of the student and on the instrument on which the music is performed. "The ultimate goal may be to play on the notes of simpler compositions, but also music playing, musical awareness, assistance in memorizing music, expressing yourself with music" (Vidulin, 2018, 140).

Dobrota (2012) points to the problem of poor equipment of Croatian schools with Orff instruments and to the phenomena in practice that imply the inappropriate use of certain rhythmic and melodic percussion. Thus, it happens that students perform accented beats on triangles, and unaccented beats on drums, that is, they perform rhythm on triangles, and beats on wooden claves. Therefore, when assigning roles to individual instruments, both their sound color and volume must be taken into account. When it comes to melodic percussion, "simple melodies of several tones or a constant melodic-rhy thmic pattern as an accompaniment to a song" should be performed on them (Dobrota, 2012, 29).

The results of a previously conducted survey in Osijek-Baranja County (Svalina, 2015) showed that teachers felt more competent in conducting singing, listening to music and playing music than in conducting playing instruments. Higher importance of playing instruments is given by younger teachers and teachers with a university degree. They consider this activity more important and are more likely to conduct it in music teaching than older teachers and teachers with higher education.

\section{Musical Creativity}

Students can engage in musical creativity activities by improvising on rhythmic and melodic percussion, or with the body percussion, by creating new simple melodies, by creating melodies to a given text, by changing familiar songs, or by transforming melodies by varying, harmonizing, expressive shaping (dynamics, articulation, and tempo) and orchestration (Ginocchio 2003; Moore 1990; Paynter-Aston 1975; Svalina, 2010; Wiggins 1989).

The Croatian Primary School Curriculum $(2006,68)$ states that performing musical creativity activities in children "sharpens certain musical abilities (intonation, rhythm), develops a sensibility for music, promotes imaginative musical expression and confidence in performing new ideas."

Tomerlin (1969) pointed out that musical creativity is not well nurtured in primary schools. In the first four grades because of the teachers' lack of competence to work in this field, and in the fifth through eighth grades, because of the understanding that these activities should be carried out so that students write their tunes. According to Tomerlin, this is still a difficult task for primary school students. Results in the field of children's musical creativity can only be achieved if the activities are carried out in such a way that the tasks correspond to the students' abilities and experience. For children, musical creativity activities should be a joyful play with music aimed at creating a new melody (Tomerlin, 1969). 
Dobrota (2012) believes that the issue of musical creativity activities in music teaching at the primary level of education is quite methodologically undeveloped and causes skepticism among many teachers and music pedagogues:

"Without going deeper into the analysis of these music activities, we will stick to the view that contemporary music pedagogy has not yet found the optimal way to realize music, or a way to make musical creativity activities truly musical, achievable, and interesting to children." (Dobrota, 2012, 33)

According to the results of a survey conducted in schools in Osijek-Baranja County (Svalina, 2015), teachers assess their competencies for leading musical creativity activities as well. However, concerning all other activities (singing, listening to music, musical games, playing an instrument), teachers consider themselves the least competent to conduct musical creativity activities. This activity is considered the least important and is the least frequently performed in music teaching. Younger teachers and "teachers with a university degree feel more competent in musical creativity activities and spend more often in music teaching than teachers with higher education" (Svalina, 2015, 179).

\section{Musical Games}

In music teaching, it is necessary to develop the ability to experience, the ability to feel the beauty of music, the creative ability of students, their imagination, and individuality. In this sense, playing games is also of great importance, because it is at the same time the need for every child, but also learning and a form of upbringing. In literature, a musical game is most often described as an activity that children start on their own in which they can voluntarily get involved and participate together with other children. As with other forms of play, musical games are enjoyable for children and they are intrinsically motivated to participate in them (Isenberg, \& Jalongo, 2000; Marsh, \& Young, 2006; Rogers, \& Sawyers, 1988). Through musical games, the students' ability to express music, especially its character or some of its expressive means, is also developed. For children to harmonize movements and music, they must actively listen to the music and feel its pulsation, and thus develop their ability to receive and experience music (Manasteriotti, 1988).

According to the Croatian Primary School Curriculum (2006), musical games are not a separate teaching area in the first three grades of primary school, but classroom teachers still implement them in music teaching. In music teaching, students can perform singing games, instrumental musical games, musical dramatizations and creative games. Singing games are most often conducted in the classroom. Manasteriotti (1988) divided them into circle singing games, column games, free-form games and mixed-form games. In games that are performed in the form of a connected or disconnected circle, "children collectively mimic individual scenes contained in the lyrics of a song with stylized movements. In some games, the action is performed by one child who invites the other children in the circle to make certain movements" (Manasteriotti, 1988, 75). Games in which children are lined up one after the other or one beside the other are called column 
games. Usually, there is a player with a lead role, but such roles may be permanent or may change during the repetition. The most complex group of games are free-form games. They are not performed in a fixed form regarding the movement in order not to hinder the individual creativity of children. There are more mixed-form games that run in two or more basic forms. Such games are a combination of two or more basic shapes, e.g. columns with free movement. They cover contents that relate to living things (humans and animals), but they can also refer to inanimate objects (Manasteriotti, 1988).

Domonji (1986) also talks about games performed with instrumental music. In such games, children move to music played on the instrument by their teacher or with music played on a player (CD player, computer, etc.). Before adopting and performing the movement, it is important that the children are well acquainted with the music, "its rhythmic-melodic flow, as well as its tempo, dynamics and form. It is only after they have mastered the music (as they did when singing) that movements are added" (Domonji, 1986, 43).

The results of a survey conducted in schools in Osijek-Baranja County (Svalina, 2015) showed that teachers have good competencies for conducting musical games, but consider this activity less important and conduct musical games less frequently than singing and listening to music.

\section{Methodology}

\section{Aim and Hypotheses of Research}

The aim of the research was to determine the opinion of students in the first, second, and third grade of primary school about music teaching and certain music activities performed during music lessons, and whether students' responses to satisfaction with certain music activities differ according to their age. The research starts from the following seven hypotheses:

H1 - Students in the first three grades of primary school love music lessons.

$\mathrm{H} 2$ - Positive emotions prevail during music lessons.

H3 - The most preferred music activity for most students is singing.

H4 - The least preferred activities for most students are musical creativity activities.

H5 - During music lessons, singing activity is most commonly performed.

H6 - The music activities that students prefer are consistent with the music activities most commonly performed in music lessons.

$\mathrm{H} 7$ - The ratings of individual music activities vary significantly with the age of the student. 


\section{Research Participants}

The survey was conducted at Fran Krsto Frankopan Primary School in Osijek (Croatia) in June 2019. The study involved first, second, and third grade primary school students (two classes of first, second, and third grades each). These were students between the ages of seven and ten.

We conducted the study in accordance with the Code of Ethics for Research with Children, adopted by the Council for Children of the Government of the Republic of Croatia in 2003. This means that parents and guardians gave us written consent to participate in the research after informing them of the purpose of the research, the type and duration of the research, the confidentiality of the information obtained, the protection of participants' privacy, the willingness to participate, and the right to opt out of the research.

\section{Method}

In conducting the research, we used appropriate procedures and instruments to collect the data. We used the survey as a procedure and the questionnaire as an instrument. The survey was anonymous. The survey questionnaire consisted of a total of nine questions. The first two questions concerned the gender and age of the students. The following were two questions through which we checked to see if students liked music classes and how they felt during those classes. Fifth and sixth were multiple choice questions where students were asked to choose one they liked the best and the one they liked the least from the listed music activities. Through the seventh and eighth questions, we wanted to find out which music activity most often occurs in music teaching and what music activity students would like to appear more frequently in music teaching. In the last question, we look at how students experience music activities that take place in music teaching. In doing so, we used a subscale Likert-type scale $(1=$ dislike it completely, $2=$ dislike it, $3=$ neither like it nor dislike it, $4=$ like it, and $5=$ really like it).

We used quantitative analysis to process and analyse the data. Based on the obtained results, we calculated the basic descriptive parameters and used certain procedures of inferential statistics. Statistical data processing was performed with the help of the software package SPSS Statistics V26. We used the nonparametric Kruskal-Wallis test $(\mathrm{H})$ to compare differences in responses regarding students' age (Petz, 2007; Suzić, 2007). Statistical significance was set at 0.05 .

\section{Research Results}

A total of 113 students participated in the survey. Out of this number, there were 34 first-grade students (30.01\%), 40 second-grade students (35.4\%) and 39 third-grade students (34.51\%). There were 53 girls (46.9\%) and 60 boys (53.1\%). 
We asked the students if they liked music classes. Out of the total number of students (113), 100 students (88.49\%) indicated that they liked music classes, and 13 students (11.5\%) indicated that they disliked music classes. In the first grade, 32 out of 34 students answered yes, in the second 36 out of 40 students, and in the third 32 out of 39 students. Thus, the research confirmed the first hypothesis (H1) according to which we assumed that students who are in the first three grades of primary school like music classes.

Although most students point out that they like music classes, the data shows that the number of students who say they don't like music classes gradually increases as their age increases. In the first grade 2 out of 34 students declare that they do not like music classes, in the second 4 out of 40 students, and in the third 7 out of 39 students (Figure 1).

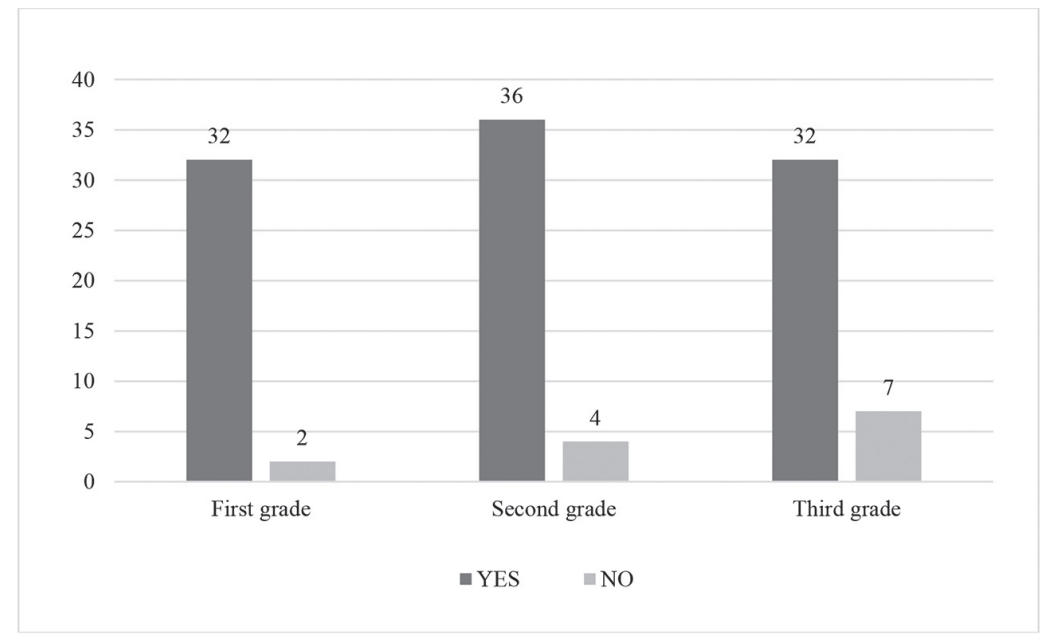

Figure 1. Number of Students per Class in Relation to Whether They Like Teaching Music

The next question was: "How do you feel while participating in music activities?". The students had multiple choice options, and the options were: happy, bored, interested and sad. The total number of students who feel happy during music lessons is $68(60.2 \%)$, 34 students are interested (30.09\%), 11 students (9.74\%) have completed the answer "I am bored", and no student states that he feels sad during music lessons. Accordingly, the second hypothesis $(\mathrm{H} 2)$ of the research was confirmed according to which we assumed that positive emotions prevail during music lessons.

Figure 2 shows that 23 first-grade students feel happy during music lessons, 9 students feel interested and 2 students feel bored. In the second grade, 22 students feel happy, 15 students feel interested and 3 students feel bored. In the third grade, 23 students feel happy, 10 students feel interested and 6 students feel bored. No student feels sad during music lessons. We can see that an equal number of students in different grades feel happy during music lessons. However, the number of students who are bored during music lessons increases with the age or class that students attend. 


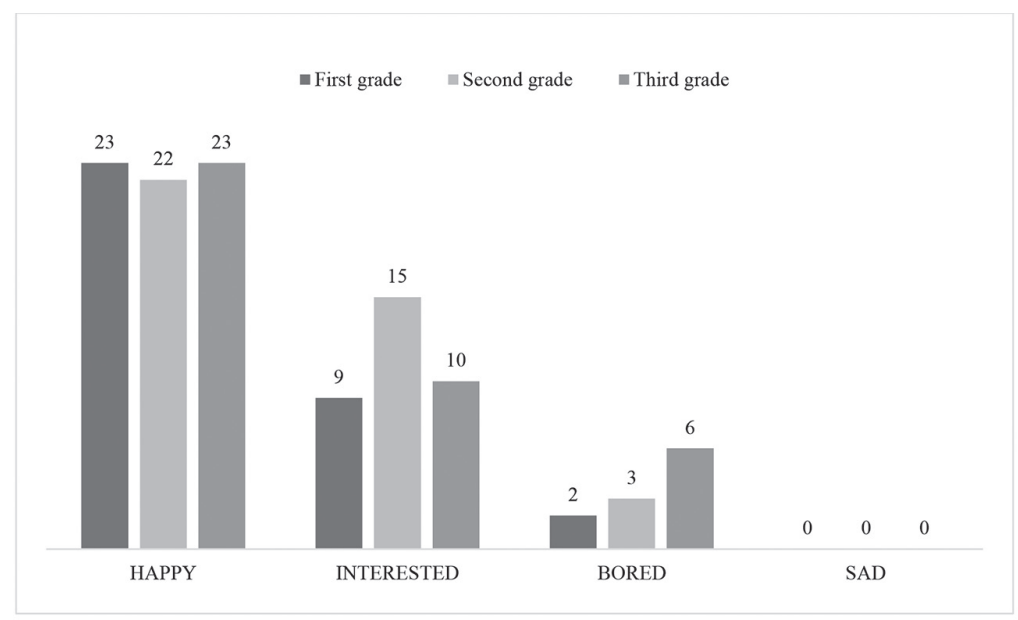

Figure 2. Number of Students per Class in Terms of How They Feel while Participating in Music Activities

The following were two questions related to checking preferences of music activities in students. In the fifth question, the students needed to check the music activity they liked the best, and the activities offered were musical games, musical creativity activities, singing, listening to music, and playing an instrument. The results showed that most students (65 students, 57.52\%) choose musical games as the activity they like the best (Table 1). Therefore, we can say that musical games are the most preferred music activity, not singing, as we hypothesized in the third research hypothesis. Accordingly, we reject the third hypothesis (H3). As an activity they like the most, they still emphasize singing, playing an instrument, creating music, and listening to music. 23 students said they liked singing the most (20.35\%), 19 students (16.81\%) liked playing an instrument the most, 3 students (2.65\%) liked musical creativity activities most, and 3 students (2.65\%) loved listening to music.

Table 1

Music Activities that Students like the Most

\begin{tabular}{lccccccccc}
\hline \multirow{2}{*}{$\begin{array}{c}\text { Music activity that } \\
\text { students like the most }\end{array}$} & \multicolumn{2}{c}{ First grade } & \multicolumn{2}{c}{ Second grade } & \multicolumn{2}{c}{ Third grade } & \multicolumn{2}{c}{ Total } \\
\cline { 2 - 11 } & $f$ & $\%$ & $f$ & $\%$ & $f$ & $\%$ & $f$ & $\%$ \\
\hline Singing & 6 & 17.65 & 9 & 22.5 & 8 & 20.51 & 23 & 20.35 \\
\hline Listening to music & 0 & 0 & 1 & 2.5 & 2 & 5.13 & 3 & 2.65 \\
\hline Musical games & 15 & 44.12 & 24 & 60 & 26 & 66.67 & 65 & 57.52 \\
\hline Playing an instrument & 11 & 32.35 & 6 & 15 & 2 & 5.13 & 19 & 16.81 \\
\hline Musical creativity activities & 2 & 5.88 & 0 & 0 & 1 & 2.56 & 3 & 2.65 \\
\hline Total: & 34 & 100 & 40 & 100 & 39 & 100 & 113 & 100 \\
\hline
\end{tabular}


Table 1 shows that in the first grade, 15 students cited musical games as the activity they liked the best. This was followed by playing an instrument chosen by 11 students, singing chosen by 6 students, and finally by a musical creativity activity selected by 2 students. No first-grade student chose listening to music for the activity he/she liked the best. In the second grade, most students (24) choose musical games as the activity they like the best, 9 students chose singing, 6 students playing an instrument, and one student listening to music. No second-grade students chose musical creativity activity as the activity they liked the best. And in third grade, most students (26) chose musical games as their favourite activity. A total of 8 students chose singing, 2 students each listening to music and playing an instrument, and only one student chose musical creativity activities. Thus, the results show that interest in musical games grows in accordance with the age of the students, while the interest in playing an instrument decreases as the age of the students' increases. There are no major differences in the students' opinions about other music activities (singing, listening to music, and musical creativity activities) regarding the age of the student.

In question six, students needed to check the music activity they liked the least (Table 2). According to the fourth research hypothesis, we assumed that students liked musical creativity activities the least. Compared to other activities, students most often state that they like music creativity activities the least (41 students, $36.28 \%$ ), which means that the fourth research hypothesis (H4) was confirmed. Students also singled out singing (25 students, 12\%), playing an instrument (24 students, 21.24\%), and listening to music (20 students, 17.70\%) as the least liked activity. Only 3 students (2.65\%) said they liked musical games the least.

Table 2

Music Activities that Students Like the Least

\begin{tabular}{lccccccccc}
\hline \multirow{2}{*}{$\begin{array}{c}\text { Music activity that } \\
\text { students like the least }\end{array}$} & \multicolumn{2}{c}{ First grade } & \multicolumn{3}{c}{ Second grade } & \multicolumn{2}{c}{ Third grade } & \multicolumn{2}{c}{ Total } \\
\cline { 2 - 10 } & $f$ & $\%$ & $f$ & $\%$ & $f$ & $\%$ & $f$ & $\%$ \\
\hline Singing & 10 & 29.41 & 6 & 15 & 9 & 23.08 & 25 & 22.12 \\
\hline Listening to music & 6 & 17.65 & 4 & 10 & 10 & 25.64 & 20 & 17.70 \\
\hline Musical games & 3 & 8.82 & 0 & 0 & 0 & 0 & 3 & 2.65 \\
\hline Playing an instrument & 5 & 14.71 & 8 & 20 & 11 & 28.20 & 24 & 21.24 \\
\hline Musical creativity activities & 10 & 29.41 & 22 & 55 & 9 & 23.08 & 41 & 36.28 \\
\hline Total: & 34 & 100 & 40 & 100 & 39 & 100 & 113 & 100 \\
\hline
\end{tabular}

Table 2 shows that 10 out of 34 first-grade students chose musical creativity activities and singing as the least liked the activity. This was followed by listening to music (6), playing an instrument (5), and musical games (3). In the second grade, out of 40 students, the majority of them chose musical creativity activities as the least liked (22). This is followed 
by playing an instrument (8), singing (6), and listening to music (4). No second-grade student chose musical games as the activity he/she liked the least. There are 39 students in the third grade. Most students chose playing an instrument as the activity they like the least (11). This is followed by listening to music (10), singing (9), and musical creativity activities (9), while no students singled out musical games.

In the seventh and eighth questions, we wanted to find out which activity is most commonly performed in music teaching and which music activities should be performed more frequently in music teaching according to the students' opinions (Table 3). Students mostly answered that singing activity was the most common (87 or $76.99 \%)$. There are fewer students who report that the most common activity is listening to music (13 or $11.51 \%$ ), playing an instrument ( 6 or $5.31 \%$ ), or playing musical games (6 or 5.31\%). Only one student answered that musical creativity activities were the most common $(0.88 \%)$.

Table 3

Activities that Students Identify as Most Common in Music Teaching

\begin{tabular}{lcccccccc}
\hline \multirow{2}{*}{ Music activity } & \multicolumn{2}{c}{ First grade } & \multicolumn{2}{c}{ Second grade } & \multicolumn{2}{c}{ Third grade } & \multicolumn{2}{c}{ Total } \\
\cline { 2 - 11 } & $f$ & $\%$ & $f$ & $\%$ & $f$ & $\%$ & $f$ & $\%$ \\
\hline Singing & 28 & 82.35 & 28 & 70 & 31 & 79.49 & 87 & 76.99 \\
\hline Listening to music & 3 & 8.82 & 4 & 10 & 6 & 15.38 & 13 & 11.51 \\
\hline Musical games & 0 & 0 & 5 & 12.5 & 1 & 2.56 & 6 & 5.31 \\
\hline Playing an instrument & 2 & 5.88 & 3 & 7.5 & 1 & 2.56 & 6 & 5.31 \\
\hline Music creativity activities & 1 & 2.94 & 0 & 0 & 0 & 0 & 1 & 0.88 \\
\hline Total: & 34 & 100 & 40 & 100 & 39 & 100 & 113 & 100 \\
\hline
\end{tabular}

When looking at the results by grades (Table 3), the majority (28) of 34 first-grade students, cite singing as the most frequent music activity. Only 3 students state that the most common activity is listening to music, 2 students state that the most common is playing an instrument and one that the most common are musical creativity activities. Students in the second grade, 40 in total, also singled out singing as the most frequent activity (28). There is also a section of students who single out musical games (5), listening to music (4), and playing an instrument (3) as the most frequent activity. Out of the responses of students attending third grade, of which there are 39 in total, most of the answers (31) are that singing is the activity that most often occurs in music teaching. There are 6 other students who emphasize that listening to music is the most common activity, one student who singles out playing an instrument and one who singles out musical games. Thus, the fifth hypothesis (H5), according to which singing is the most common activity in teaching music, is confirmed by the research results.

From the answers to the eighth question, we learned what music activities students would like to do more often in music classes (Table 4). Most students (77 or 68.14\%) ans- 
wered that they wanted to participate in musical games more often, 15 students (13.27\%) wanted to play instruments more often, 12 students (10.62\%) wanted to listen to music more often, 5 students $(4.42 \%)$ wanted to participate more often in musical creativity activities, and 4 students (3.54\%) want to sing more often.

Table 4

Activities that Should be Carried out More Often in Music Class According to Students

\begin{tabular}{lcccccccc}
\hline \multirow{2}{*}{ Music activity } & \multicolumn{2}{c}{ First grade } & \multicolumn{2}{c}{ Second grade } & \multicolumn{2}{c}{ Third grade } & \multicolumn{2}{c}{ Total } \\
\cline { 2 - 10 } & $f$ & $\%$ & $f$ & $\%$ & $f$ & $\%$ & $f$ & $\%$ \\
\hline Singing & 1 & 2.94 & 3 & 7.5 & 0 & 0 & 4 & 3.54 \\
\hline Listening to music & 1 & 2.94 & 6 & 15 & 5 & 12.82 & 12 & 10.62 \\
\hline Musical games & 25 & 73.53 & 26 & 65 & 26 & 66.67 & 77 & 68.14 \\
\hline Playing an instrument & 5 & 14.71 & 4 & 10 & 6 & 15.38 & 15 & 13.27 \\
\hline Musical creativity activities & 2 & 5.88 & 1 & 2.5 & 2 & 5.13 & 5 & 4.42 \\
\hline Total: & 34 & 100 & 40 & 100 & 39 & 100 & 113 & 100 \\
\hline
\end{tabular}

When looking at the results by grades (Table 4), it can be observed that students provide similar answers for all activities except for listening to music. Specifically, this activity should be conducted more frequently in the teaching of music according to the opinion of one out of 34 first grade students, 6 out of 40 second grade students, and 5 out of 39 third grade students. Other activities are distinguished by first, second, and third grade students in equal proportions. In the first grade, 25 out of 34 students cite musical games as an activity they would like to spend more time on in music classes, 5 students single out playing an instrument, 2 students want to participate more often in musical creativity activities and one student wants to sing and listen to music more often. In the second grade, 26 out of 40 students say they want to participate in musical games more often, 6 students want to listen to music more often, 4 students want to play instruments more often, 3 students want to sing more often and one to participate more often in the activity of musical creativity. In third grade, 26 out of 39 students want to participate in musical games more often, 6 students want to play instruments more often, 5 students want to listen to music more often, 2 students want to participate more often in musical creativity activities, and no student states that they want to sing more often in music classes.

Since the results of the research have shown that musical games are the favourite activity for the students and the most frequent activity is singing, we can say that we have not confirmed the sixth hypothesis (H6) according to which we assumed that the music activities that students most prefer are in line with the most frequently performed music activities in teaching music.

In the ninth question, students were asked to show how satisfied they were with the music activities performed in music classes. They had to do this by assigning each activity 
a grade of 1 to 5 . To make it clear what the activity was before the students started giving their answers, we briefly described each music activity. The music activities that students evaluated were singing, listening to music, musical games, playing an instrument, and musical creativity activities.

Table 5 shows the results from which it is evident that the first-grade students highly value all five music activities. Average values range from 4.18 to 4.79 . Second-grade students value musical games $(M=4.75)$, listening to music $(M=4.48)$, playing an instrument $(M=4.43)$, and singing $(M=4.4)$. For musical creativity activities, students give a very good but still slightly

lower grade $(M=3.7)$. Third grade students value musical games $(M=4.44)$, listening to music $(M=4.05)$ and singing $(M=4.03)$. For third grade students, two activities were rated slightly lower. These are playing an instrument $(\mathrm{M}=3.87)$ and musical creativity activities $(\mathrm{M}=3.59)$.

Table 5

Students' Statements about Satisfaction with Music Activities with Respect to their Age (Mean Values and Dispersion of Scores)

\begin{tabular}{lcccccccccc}
\hline \multirow{2}{*}{ Music activity } & \multicolumn{4}{c}{ First grade } & \multicolumn{3}{c}{ Second grade } & \multicolumn{2}{c}{ Third grade } \\
\cline { 2 - 10 } & $\mathbf{N}$ & Mean & $\begin{array}{c}\text { Std. } \\
\text { Deviation }\end{array}$ & N & Mean & $\begin{array}{c}\text { Std. } \\
\text { Deviation }\end{array}$ & N & Mean & $\begin{array}{c}\text { Std. } \\
\text { Deviation }\end{array}$ \\
\hline Singing & 34 & 4.18 & 1.24 & 40 & 4.4 & 1.01 & 39 & 4.03 & 1.53 \\
\hline Listening to music & 34 & 4.59 & .70 & 40 & 4.48 & .85 & 39 & 4.05 & 1.17 \\
\hline Musical games & 34 & 4.65 & .65 & 40 & 4.75 & .59 & 39 & 4.44 & 1.14 \\
\hline $\begin{array}{l}\text { Playing an instru- } \\
\text { ment }\end{array}$ & 34 & 4.79 & .64 & 40 & 4.43 & 1.06 & 39 & 3.87 & 1.54 \\
\hline $\begin{array}{l}\text { Musical creativity } \\
\text { activities }\end{array}$ & 34 & 4.32 & .91 & 40 & 3.7 & 1.11 & 39 & 3.59 & 1.43 \\
\hline
\end{tabular}

By comparing the responses of the first, second and third grade students to their satisfaction with certain activities, we noticed differences in the age of the students (Table 5). Singing is in first grade in the last place, in second grade in the fourth place, and in third grade in the third place. Playing an instrument in the first grade is the highest rated music activity, while in the second grade it is in the third place and in the third grade it is in the fourth place. Interest in musical games increases in the second grade compared to the first, and then falls again in the third grade. Nevertheless, musical games are the highest rated activity in both second, and third grade.

Grades for listening to music, playing an instrument, and for musical creativity activities are gradually decreasing with students' age. The largest decrease was observed in the evaluation of playing an instrument and musical creativity activities (Table 5). With the Kruskal-Wallis H-test, we checked whether differences in students' responses 
to satisfaction with music activities concerning their age were statistically significant (Table 6). The result of the Mann-Whitney U-test showed that there was a statistically significant difference in students' responses to satisfaction with playing an instrument between first and third grade $(H=9,634, p=0.002)$ at the 0.01 level and satisfaction with musical creativity activities between first and second grade $(\mathrm{H}=6.430, \mathrm{p}=0.011)$ and first and third grade $(H=5.333, p=0.021)$ at the 0.05 level. Differences in students' responses to their enjoyment of musical games, singing and listening to music were not statistically significant.

Table 6

Differences in Student Responses on their Satisfaction with Certain Music Activities by Student Age - Mann-Whitney U-Test

\begin{tabular}{lcc}
\hline \multicolumn{1}{c}{ Music activity } & $\begin{array}{c}\text { Kruskal-Wal- } \\
\text { lis H }\end{array}$ & $\begin{array}{c}\text { Asymp. } \\
\text { Sig. }\end{array}$ \\
\hline Singing & .546 & .761 \\
\hline Listening to music & 5.475 & .065 \\
\hline Musical games & 1.213 & .545 \\
\hline Playing an instrument & 9.994 & .007 \\
\hline Musical creativity activities & 7.542 & .023 \\
\hline
\end{tabular}

The results, therefore, indicate differences in students' responses concerning their age, i.e., a gradual decrease in students' interest in three of the five music activities (for playing an instrument, musical creativity activities and listening to music), which means that the seventh hypothesis (H7) is partially confirmed.

\section{Discussion}

The findings of the research show that the vast majority of students (88.49\%) like music lessons, but also that this number decreases as the age of students increases. Similar are the results of previous research which also confirmed that students have positive attitudes about the subject, but that interest gradually decreases with the age of students (Dobrota, \& Conar, 2018; Dobrota, \& Obradović, 2012; Dobrota, \& Reić Ercegovac, 2011; Haladyna, \& Thomas, 2015). In addition to this, the results of previous research show that, although students love music lessons, Music is not their favorite subject in school. According to the results of research conducted in primary schools in Osijek-Baranja County (Svalina, 2015), favorite subject for students of the first four grades is Physical Education (PE), while music teaching is in fifth place. According to the results of this research, only one fifth of the students (20\%) single out music teaching as their favorite 
subject. The results of research conducted by Haladyna and Thomas (2015) show that first, second and fourth-grade students prefer Art, while third-grade students prefer Physical Education. According to this research, Music ranks third in terms of popularity among students in the first four grades of primary school. Should reason for reducing interest in music teaching be found in inappropriate teaching content, in the selection of activities carried out in teaching music classes, in applied teaching strategies and procedures, or something else? It would certainly be good to answer this question in one of the following researches.

The results also showed that students feel cheerful and interested in music lessons, which means that positive emotions prevail during such lessons. It is possible that such positive emotions are related to the positive influence that music normally has on a person. The results of some previous research have shown that music in major tonalities and music in fast tempos evokes positive emotions in humans (Dobrota, \& Reić Ercegovac, 2012; Mohn et al., 2011; Peretz et al., 1998). This is exactly the characteristic of most of the songs and compositions that students get to know in Croatian primary schools in the first three grades.

Students state that singing activities are most often carried out in music lessons, but they do not mention singing as their favorite activity, but musical games. At the same time, interest in musical games is gradually growing as the age of students increases. According to the Croatian Curriculum for Primary School (2006), musical games are not envisaged as an independent teaching area in any of the first three grades, and they are mentioned as a recommended activity only in the first grade curriculum when talking in more detail about activities within the teaching areas of singing and elements of musical creativity. The results of research conducted in Croatian schools in Osijek-Baranja County (Svalina, 2015) showed that musical games are in third place in terms of the frequency of conducting music activities and that they are performed much less often than singing and listening to music.

Numerous studies have been conducted that indicate the importance of musical games in the overall development of a child. Musical games, like all other games, develop intellect, contribute to the development of a versatile personality, and enrich a child's psychic life (Kouvava et al., 2011; Møller et al., 2002). According to the results of research conducted to find out the effectiveness of teaching in which games are conducted by learning through play, better results are achieved compared to classical learning. By introducing musical play in the classroom, we make the classroom much more interesting, create a pleasant atmosphere in the classroom, increase student attention and motivation, but also encourage the student's own activity (Marjanović Umek, \& Zupančić, 2001; Sawyer, 2001; Smith, \& Simon, 1984).

The results of our research showed that musical creativity is the least favorite activity. That is the opinion of one third of the students (36.28\%). A quarter of the students (25.12\%) singled out singing as their least favorite activity, a fifth playing an instrument (21.24\%), 
and slightly less than a fifth of the students listening to music (17.70\%). We can say that these results are in line with previous research in Croatian primary schools (Svalina, 2015) according to which the activity of music creation is the rarest conducted activity in music teaching, and teachers feel the least competent to lead it. And in that research also a small number of students stated that music creation is their favorite activity. There are other studies in which the results show that in some other countries, musical creative activities are carried out less frequently than other music teaching activities. Thus, in the United States, improvisation is the least popular and least represented activity (Byo, 1999), and in the United Kingdom, improvisation is not even carried out in music teaching (Koutsoupidou, 2005). Koutsoupidou (2005) points out that teachers in the United Kingdom did not include improvisation in music teaching due to their lack of experience in improvisation and lack of knowledge of how to teach that activity.

Musical creativity activities should have their place in music teaching as well as other musical activities. Students can engage in this activity by changing familiar songs, creating new simple melodies, and improvising with music using a variety of rhythmic or melodic percussion (Moore, 1990; Wiggins, 1989). Musical creativity activities can be carried out individually or in groups. They can be conducted individually by students exploring sounds independently on a musical instrument (Kratus, 1991) or by improvising individually within a larger form (Moore 1990). In group musical creativity activities, students can be given the task of designing a shorter percussion composition (e.g., an ABA-shaped piece) to perform in front of the entire class (Welwood, 2001; Wiggins, 1989).

In our research, the results showed that singing is the most common activity in music teaching. Such an answer was given by $76.99 \%$ of students, while a smaller number cited listening to music (11.51\%), playing an instrument (5.31\%) and musical games (5.31\%) as more frequent activities. Singing as the most common activity in music teaching at the primary level of education has been shown by the results of some previous research (Price, \& Burnsed, 1989; Svalina, 2015). The results obtained in a study conducted in Croatian primary schools in Osijek-Baranja County (Svalina, 2015) showed that according to the teachers, singing is the most important and most frequent activity in music teaching at primary education, and according to students teachers are most successful precisely in conducting singing activities. The results of a survey conducted in English primary schools showed that singing is a musical activity which all children can join in with, and which all staff can develop the confidence to support and lead. "Singing can become an integral part of the school day or can be an activity undertaken primarily in specialist lesson time. Every type of singing can be enjoyable and rewarding for all involved" (Lamont et al., 2012, 262).

It is expected that the teachers most often conduct singing in music lessons because this activity can be carried out more or less successfully in almost all conditions, regardless of the equipment of classrooms such as certain musical instruments, devices, etc. However, when striving for better music teaching it is not enough to conduct musical 
activities frequently. It is necessary to implement them with quality. Quality guidance of this activity will be achieved if teachers sing in class, if they sing correctly and in tonalities that are consistent with the range of children's voices, if they accompany their singing on a harmonic musical instrument (piano, synthesizer, guitar or harmonica) and if their playing is skilful, that is, if the singing and playing are well coordinated.

The results of the research show that students very rarely single out the activity of listening to music as their favorite activity (2.65\%). Also, the number of those students $(17.70 \%)$ who cite listening to music as the activity they like the least is not negligible. Although students highly value the activity of listening to music, these grades gradually decrease with the increasing age of students. Given the results obtained, we can say that the activity of listening to music does not have the place in music teaching that it is given by the Croatian Curriculum for Primary School (2006) according to which listening to music should have a central place in music teaching. Vidulin-Orbanić (2012) believes that not enough attention is paid to the arts in schools and that it is necessary to raise the art of music and culture to an appropriate (worthy) level through artistic (musical) education. In the first three grades of primary school, it is necessary (and possible) to perform the activity of listening to music as often as possible, provided that the approach to this activity should be appropriate for the age of the students. To listen to music in the first three grades of primary school, teachers do not have to choose only compositions intended for children, ie program compositions, but also other compositions of shorter duration. Repeated listening is required to experience the work and to notice all the musical components. Through such listening, students notice "hidden" details, which they are not able to notice when first introduced (Vidulin-Orbanić, 2002). Listening should be accompanied by tasks that will arouse students' interest, which will serve as an aid in finding their way in abstract musical work and as strongholds around which they will focus their attention (Dobrota, 2012).

When it comes to the activity of playing an instrument, the results of our research show that this activity is the third favorite for students. Only $16.81 \%$ of students choose this activity as their favorite activity. For first-graders, playing an instrument is the second most popular activity (right after musical games), and in the second and third grade, playing an instrument is in third place. Students also state that playing an instrument is not a frequent activity in music teaching. Students highly value the activity of playing an instrument, but these grades also decrease with the increasing age of students. The difference in the answers of the students from the first, second, and third grade turned out to be statistically significant. According to the research conducted by Svalina (2015) in the first three grades of primary school, playing an instrument is the fourth most frequent activity and is more often performed by younger teachers, teachers with higher education, and teachers who accompany their and students' singing in music lessons by playing a harmonic instrument. This research has shown that playing is an activity that children look forward to, but it is difficult to achieve in music teaching in the absence 
of an adequate number of rhythmic and melodic percussion. Teachers point out as a problem that schools do not provide them with good enough working conditions, ie well-equipped classrooms for music teaching (Svalina, 2015). Dobrota points out that "playing an instrument should be introduced into music teaching for psychological and musical reasons. These activities are necessary because students love them and because they develop their musical abilities" (Dobrota, 2012, 100).

\section{Conclusion}

With this research, we found that students love music classes and are satisfied with all the music activities they are a part of, but that satisfaction decreases with the increase in age of students in three out of five activities: listening to music, playing an instrument, and musical creativity activities. The biggest drop was observed in the students' responses to the pleasure of playing an instrument and musical creativity activities. Similar results are shown by previous research (Svalina, 2015) according to which these two activities are rarely performed in music teaching and teachers feel less competent to perform them than to conduct singing, listening to music, and musical games. Therefore, more attention should be paid to empowering teachers' competences to lead playing an instrument and musical creativity activities through their lifelong education. In addition, it is necessary to achieve better preparation for future teachers in teacher training for the management of these two activities.

It seems that Croatian schools also need a slightly different approach to conducting musical creativity activities, because students are singling out that they are the least satisfied with this activity. Also, it is necessary to determine why students are least likely to enjoy musical creativity activities. If we find out the reasons, we will be able to change what is needed to bring the listed music activity as close as possible to the students.

Teachers still need to consider the fact that singing is the most common music activity in music teaching, but not the activity in which the students enjoy participating the most. This does not mean that the share of singing in music teaching should be reduced, but that more emphasis should be placed on the activity that is most interesting to students, namely musical games.

Children love musical games because they meet them from an early age, and interest in them does not stop even when they go to school. During musical games children sing, play, move, and perform dance moves. Classes are less monotonous and children are more satisfied. With such activities, the classroom is filled with laughter and joy. It is an activity that can be carried out quite well by all teachers, even those with weaker musical competencies. Although musical games have a more recreational character, it should be emphasized that they, as well as other musical activities, can develop various children's musical abilities. 
More often, connecting games with singing activities, as well as with all other activities performed in music teaching (playing an instrument, listening to music, and musical creativity activities), will consider the desires and needs of students, which is certainly necessary. Any change that is in line with the student's needs and desires contributes to the quality of teaching which further contributes to the student's motivation. Students are more active in teaching, learn more easily, develop their musical skills, and their interest in music.

\section{References}

Byo, S. J. (1999). Classroom teachers' and music specialists' perceived ability to implement the National Standards for music education. Journal of Research in Music Education, 47, 111-123. doi:10.2307/3345717

Dobrota, S. (2012). Uvod u suvremenu glazbenu pedagogiju [Introduction in contemporary music pedagogy]. Split: Filozofski fakultet u Splitu - Odsjek za učiteljski studij. [Google Scholar]

Dobrota, S., \& Conar, R. (2018). Stavovi učenika prema nastavi Glazbene kulture i Glazbene umjetnosti [Students' attitudes towards music culture and musical art]. Život i škola, 64(1), 131-139. [Google Scholar]

Dobrota, S., \& Ćurković, G. (2006). Glazbene preferencije djece mlađe školske dobi. [Musical preferences of young learners.] Život i škola: časopis za teoriju i praksu odgoja i obrazovanja, 52, 15-16, 105-113. [Google Scholar]

Dobrota, S., \& Obradović, I. (2012). Stavovi učenika osnovne škole prema glazbi i nastavi glazbe [Attitudes of primary-school pupils toward music and music education]. Školski vjesnik: časopis za pedagogijsku teoriju i praksu, 61(1-2), 115-131. [Google Scholar]

Dobrota, S., \& Reić-Ercegovac, I. (2011). Stavovi učenika prema glazbi i nastavi glazbene kulture [The attitudes of pupils toward music education and to music in general]. Školski vjesnik: časopis za pedagoška i školska pitanja, 60(2), 199-210.

Dobrota, S. \& i Reić Ercegovac, I. (2012). Odnos emocionalne kompetentnosti i prepoznavanja emocija u glazbi [The relationship between emotional competence and recognizing emotions in music]. Društvena istraživanja: časopis za opća društvena pitanja, 21(4), 969-988. [Google Scholar]

Dobrota, S. \& i Reić Ercegovac, I. (2016). Zašto volimo ono što slušamo: glazbeno-pedagoški i psihologijski aspektiglazbenih preferencija [Why we love what we listen to: Music-pedagogical and psychological aspects of musical preferences]. Split: Filozofski fakultet u Splitu. [Google Scholar]

Domonji, I. (1986). Metodika muzičkog vaspitanja u predškolskim ustanovama. [Methods of music education in preschool institutions.] Sarajevo: Svjetlost. [Google Scholar]

Fung, C. V., Lee, M., \& Chung, S. E. (1999/2000). Music style preferences of young students in Hong Kong. Bulletin of the Council for Research in Music Education, 143, 50-64. [Google Scholar] 
Ginocchio, J. (2003). Making composition work in your music program. Music Educators Journal, 90(1), 51-56. [Google Scholar]

Haladyna, T., \& Thomas, G. (2015). The attitudes of elementary school children toward school and subject matters. The Journal of Experimental Education, 48(1), 18-23. doi: 10.1080/00220973.1979.11011707

Isenberg, J. \& Jalongo, M. (2000). Creative expression and play in early childhood ( $3^{\text {rd }}$ ed.). Upper Saddle River, NJ: Merrill Prentice Hall.

Koutsoupidou, T. (2005). Improvisation in the English primary music classroom: Teachers' perceptions and practices. MusicEducation Research, 7,363-381. doi:10.1080/14613800500324432

Kratus, J. (1991). Growing with Improvisation. Music Educators Journal, 78(4), 35-40. doi: 10.2307/3398335

Lamont, A., Daubney, A., \& Spruce, G. (2012). Singing in primary schools: case studies of good practice in whole class vocal tuition. British Journal of Music Education, 29(02), 251-268. doi: 10.1017/S0265051712000083

Manasteriotti, V. (1988). Zbornikpjesama i igara za djecu - priručnik muzičkog odgoja. [Collection of Poems and Games for Children - Manual for Teaching Music]. Zagreb: Školska knjiga. [Google Scholar]

Marjanovic Umek, L., \& Zupancic, M. (2001). Teorija otroške igre. [Children play theory]. In L. Marjanovic Umek, \& M. Zupancic (Eds.), Psihologija otroške igre. Od rojstva do vstopa v solo [Children Play Psychology] (pp. 1-33). Ljubljana: Znanstveni institut Filozofske fakultete.

Marsh, K., \& Young, S. (2006). Musical play. In G. E. McPherson (Ed.), The child as musicians: A handbook of musical development (pp. 289-310). Oxford: Oxford University Press. [Google Scholar]

Mohn, C., Argstatter, H., \& Wilker, F. W. (2011). Perception of six basic emotions in music. Psychology of Music, 39(4), 503-517. doi: 10.1177/0305735610378183

Møller, A. S., Odell-Miller, H., \& Wigram, T. (2002). Indications in music therapy; evidence from assessment that can identify the expectations of music therapy as a treatment to Autistic Spectrum Disorder (ASD): meeting the challenge of evidence based practice. British Journal of Music Therapy, 16(1), 11-28. doi: 10.1177/135945750201600104

Moore, J. L. S. (1990). Strategies for fostering creative thinking. Music Educators Journal, 76(9), 38-43. [Google Scholar]

Nacionalni okvirni kurikulum za predškolski odgoj i opće obvezno obrazovanje u osnovnoj i srednjoj školi [National framework curriculum for pre-school and general compulsory education in primary and secondary schools] (2011). Zagreb: Ministarstvo znanosti, obrazovanja i športa. Nastavni plan i program za osnovnu školu. [Curriculum for Primary School] (2006). Zagreb: Ministarstvo znanosti, obrazovanja i športa.

Paynter, J., \& Aston, P. (1975). Sound and silence. London: Cambridge University Press. [Google Scholar] 
Peretz, I., Gagnon, L., \& Bouchard, B. (1998). Music and emotion: Perceptual déterminants, immediacy, and isolation after brain damage. Cognition, 68(2), 111-141. doi: 10.1016/s00100277(98)00043-2

Petz, B. (2007). Osnovne statističke metode za nematematičare [Basic Statistical Methods for Nonmathematicians]. Jastrebarsko: Naklada Slap. [Google Scholar]

Pitts, S. (2009). Roots and routes in adult musical participation: investigating the impact of home and school on lifelong musical interest and involvement. British Journal of Music Education, 26, 241-256. https://doi.org/10.1017/S0265051709990088

Price, H. E., \& Burnsed, V. (1989). Classroom teachers' assessments of elementary education music methods. Update: Applications of Research in Music Education, 8(1), 28-32. [Google Scholar]

Radočaj-Jerković, A. (2017). Pjevanje u nastavi glazbe [Singing in music lessons]. Osijek: Umjetnička akademija u Osijeku.

Rogers, C. S., \& Sawyers, J. K. (1988). Play in the lives of children. National Association for the Education of Young Children. [Google Scholar]

Rojko, P. (2012). Metodika nastave glazbe: teorijsko - tematski aspekti. [Metodics of music education. Theoretical and thematic aspects]. Osijek: Sveučilište J. J. Strossmayera, Pedagoški fakultet Osijek. [Google Scholar]

Sawyer, R. K. (2001). Play as improvisational rehearsal: multiple levels of analysis in children's play. In A. Goncü, \& E. Klein (Eds.), Children in play, story, and school (pp. 19-38). New York, NY: Guilford.

Smith, P. K., \& Simon, T. (1984). Object play, problem-solving and creativity in children. In P. K. Smith (Ed.), Play in animals and humans (pp. 199-216). Oxford: Basil Blackwell, Inc.

Spruce, G. J. (2002). Ways of thinking about music: political dimensions and educational consequences. In G. J. Spruce (Ed.), Teaching Music in Secondary Schools: A Reader (pp. 3-24). London: Routledge/Falmer.

Svalina, V. (2010). Dječje stvaralaštvo u nastavi glazbe [Children's creativity in music classroom.] In K. Káich (Ed.) Korszerü módszertani kihívások [Contemporary methodological challenges] (pp. 378-393). Szabadka: Magyar Tannyelvű Tanítóképző. [Google Scholar]

Svalina, V. (2015). Kurikulum nastave glazbene kulture i kompetencije učitelja za poučavanje glazbe [Music curriculum and teachers' competences for teaching music]. Osijek: Sveučičište J. J. Strossmayera u Osijeku; Fakultet za odgojne i obrazovne znanosti. [Google Scholar]

Suzić, N. (2007). Primijenjena pedagoška metodologija [Applied pedagogical methodology]. Banja Luka: XBS. [Google Scholar]

Vidulin, S. (2018). Sviranje u redovitoj nastavi: glazbeno-pedagoške i metodičke implikacije [Playing instrument in regular music class: musical-pedagogical and didactic implications]. In A. Bosnić, \& N. Hukić (Eds.) Muzika u društvu [Music in society] (pp. 128-144). Sarajevo: Muzikološko društvo Federacije Bosne i Hercegovine, Muzička akademija Univerziteta u Sarajevu. 
Vidulin-Orbanić, S. (2012). Utjecaj glazbene nastave na (glazbenu) kulturu učenika [Impact of music lessons on students' (musical) culture]. In N. Hrvatić, \& A. Klapan (Eds.), Pedagogija i kultura [Pedagogy and culture ], 1 (pp. 419-430). Zagreb: Hrvatsko pedagogijsko društvo. [Google Scholar]

Vidulin-Orbanić, S., \& Terzić, V. (2011). Polazište i pristup pjevanju u općeobrazovnoj školi. [Starting point and approach to singing in primary school.] Metodički ogledi, 18(2), 137-156. [Google Scholar]

Welwood, A. (2001). Improvisation with found sounds. In D. L. Hamann (Ed.), Creativity in the music classroom (pp. 93-98). Reston, VA: Music Educators National Conference.

Wiggins, J. H. (1989). Composition as a teaching tool. Music Educators Journal, 75(8), 35-38. [Google Scholar]

Wiggins, J. H. (2001). Teaching for musical understanding. New York: McGraw-Hill. [Google Scholar]

\title{
Muzikos mokymas: pradinès mokyklos mokinių (pirmos, antros ir trečios klasès) perspektyva
}

\author{
Vesna Svalina ${ }^{1}$, Jelena Zelić ${ }^{2}$
}

1 Osijeko Josipo Jurajaus Štròsmajerio universitetas, Ugdymo fakultetas, Cara Hadrijana g. 10, HR-31000 Osijekas, Kroatija, vesna.svalina@gmail.com

2 Osijeko Josipo Jurajaus Štròsmajerio universitetas, Ugdymo fakultetas, Cara Hadrijana g. 10, HR-31000 Osijekas, Kroatija, jelena.zelic19@gmail.com

\section{Santrauka}

Šiame straipsnyje aptariami tyrimo, atlikto siekiant ištirti pradinių klasių mokinių (pirmos, antros ir trečios klasès) prioritetus muzikos mokymo veiklai gerinti, rezultatai. Tyrimo tikslas atskleisti pradinės mokyklos pirmos, antros ir trečios klasės mokinių nuostatas ị muzikos mokymą ir tam tikrą muzikinę veiklą muzikos pamokų metu ir nustatyti, ar mokinių atsakymai apie pasitenkinimą tam tikra muzikine veikla priklauso nuo jų amžiaus. Tyrime dalyvavo 113 mokinių. Tyrimo rezultatai parodé, kad mokiniai mejgsta muzikos pamokas, jose vyrauja teigiamos emocijos. Mokant muzikos, dažniausiai mokoma dainavimo, tačiau mokiniai mieliau dalyvauja muzikiniuose žaidimuose. Mokiniai mažiausiai domisi muzikine kūrybine veikla. Kroatijos mokyklos mokytojams taip pat reikia šiek tiek kitokio požiūrio ị muzikinę kūrybinę veiklą, nes mokiniai pabrèžia, kad jie yra mažiausiai patenkinti šia veikla. Taip pat būtina nustatyti, kodèl mokiniai mažiausiai linkę mėgautis muzikine kūryba. Rezultatai taip pat parodè statistiškai reikšmingus skirtumus tarp mokinių nuostatų i jų pasitenkinimą grojant Orff instrumentais ir muzikinę kūrybinę veiklą pagal amžių. Mokytojai turi atsižvelgti ị tai, kad muzikiniai žaidimai 
yra labiausiai paplitusi muzikiné veikla mokant muzikos, ir žaidimus dažniau sieti su kita muzikine veikla (dainavimu, grojimu instrumentu, muzikos klausymu ir muzikinės kūrybos užsièmimais). Be to, daugiau dèmesio reikètų skirti mokytojų kompetencijoms, tokioms kaip mokinių mokymas groti instrumentu ir jų muzikinès kūrybinès veiklos skatinimas, ugdyti suteikiant mokymosi visą gyvenimą galimybes.

Esminiai žodžiai: pradinès mokyklos žemesnès klasès, muzikinè veikla, muzikos mokymas, mokiniu prioritetai. 